\title{
Occurrence of landslides during the approach of tropical cyclone Juliette (2001) to Baja California Sur, Mexico
}

\author{
J. L. ANTINAO \\ Desert Research Institute, Division of Earth and Ecosystems Sciences, 2215 Raggio Parkway, \\ Reno, Nevada 89512, USA \\ Corresponding author; e-mail: joseluis.antinao@dri.edu \\ L. M. FARFÁN \\ Centro de Investigación Científica y de Educación Superior de Ensenada, Unidad La Paz, \\ Miraflores 334, La Paz 23050, Baja California Sur, México
}

Received October 14, 2011; accepted September 14, 2012

\begin{abstract}
RESUMEN
El acercamiento del ciclón tropical Juliette en 2001 a la península de Baja California provocó por lo menos 419 deslizamientos. Éstos corresponden en su mayoría a derrumbes someros de extensión reducida que fueron convertidos rápidamente en flujos de detritos para ser exportados de las áreas montañosas hacia áreas bajas. Los factores principales que afectan la ocurrencia de deslizamientos en esta zona son la precipitación total y su intensidad, así como la orientación, la geología y la vegetación. Se pueden distinguir dos procesos como iniciadores de los derrumbes. El primero de ellos es la acumulación de escorrentía por precipitación intensa sobre rocas expuestas, lo cual genera exceso de escurrimiento superficial que acarrea regolito. Éste es el proceso principal en topografía cóncava. La combinación de viento y de exceso de escurrimiento en las pendientes altas convexas o planas constituye un proceso secundario relacionado con la heterogeneidad de las asociaciones de vegetación en el límite entre los bosques tropical seco y de roble. Los árboles arrancados desprendieron bloques completos de regolito y roca, lo cual preparó las laderas para la concentración adicional de escurrimiento superficial. Se ha estimado una curva para el umbral de deslizamientos en esta región. Asimismo, con base en el análisis de la información histórica, se ha determinado que tormentas como Juliette se acercan al sur de la península en promedio una vez cada 100 años. Las estimaciones de la denudación provocada directamente por deslizamientos se ubican en la parte más alta del espectro para un margen tectónico pasivo. Estas estimaciones deben considerarse en la toma de decisiones vinculadas con el manejo de los recursos hídricos en esta región. Los resultados acentúan la necesidad de contar con una representación más detallada de la distribución espacial de la precipitación y vientos para esta región montañosa afectada por ciclones tropicales.
\end{abstract}

\begin{abstract}
The approach of tropical cyclone (TC) Juliette, in 2001, to the Baja California Peninsula triggered at least 419 landslides. Most of the landslides were shallow slips and debris slides of limited areal extent, which were converted rapidly into debris flows to be exported quickly out of the mountain areas towards the lowlands. Main factors affecting landslide occurrence were total storm rainfall and intensity, aspect, geology and vegetation association. Two processes can be distinguished as initiating slope failure. Accumulation of rainfall from exposed bedrock slopes, generating excess overland flow, was the main process linked to failures in
\end{abstract}


concave topography. A combination of wind and excess overland flow in the more convex or planar upper slopes was a secondary process related to heterogeneity of vegetation associations in the oak-dry tropical forests ecotone, as uprooted trees dislodged large regolith and bedrock blocks, priming hillslopes for further runoff concentration. An estimative threshold curve for triggering landslides in this region is sketched. From the analysis of historical information, storms like Juliette approach the southern peninsula on average once every 100 years. Denudation estimates are in the higher end of the spectrum for a tectonically passive margin. These estimates should be considered when taking decisions regarding management of water resources in this area through damming of streams. The results emphasize the need for a more detailed representation of the spatial distribution of the rainfall and winds for this mountainous region affected by TCs.

Keywords: Tropical cyclone, eastern Pacific Ocean, Juliette, landslides, sediment transport.

\section{Introduction}

Inland landscapes affected by tropical cyclones (TC) respond in different ways to the intense precipitation generated by the storm approach and passage over the continent. Widespread flooding, bank erosion and alluvial deposition are dominant processes in lowlands (Gupta, 1988; Kostachuk et al., 2001; Martínez-Gutiérrez and Mayer, 2004; Milliman and Kao, 2005) while landslides are predominant in mountainous terrain (Larsen and Simon, 1993; Page et al., 1999; Hovius et al., 2000; Crone et al., 2001; Bucknam et al., 2001; Lin et al., 2004; Alcántara-Ayala, 2004; Turton, 2008; Larsen, 2008). All types of mass wasting events can occur during the passage of these storms. Deep seated landslides turning into mudslides have mobilized entire hillslopes (MatíasRamírez, 1998), and debris slides and flows can aggregate and have the capability of follow and overwhelm the drainage network, affecting catastrophically the landscape (Padilla-Lozoya, 2006). A large availability of sediment on the hillslopes is a major factor that conditions mass wasting under increased pore pressure, and significant geomorphic effects derived from landsliding are observed in tropical regions where deep weathering makes available larger amounts of regolith to be mobilized (e.g., Bucknam et al., 2001; Crone et al., 2001; Larsen and Torres-Sánchez, 1992). However, in certain cases slope failure can occur on hillslopes with shallow regolith cover, like those that take place in semiarid regions receiving only seasonal precipitation (Webb et al., 2008). These events are rarely described because they are less impressive compared to their counterparts in regions with relatively constant humid conditions throughout the whole year.

Our goal is to discuss the meteorological, geomorphological and environmental conditions that are favorable for landslide development in response to the approach and eventual TC landfall in the Mexican state of Baja California Sur (BCS). The area is located in a semiarid environment dominated by rainfall in discrete TC-related events during the summer and fall (Latorre and Penilla, 1988). Rainfall-triggered landslides have not been reported for the region despite the fact that the region receives at least once a year a TC passing within $250 \mathrm{~km}$ from the coast ( $c f$. Serra, 1971). Since 1969, only one category-3 made landfall in BCS (Farfán et al., 2012) although, over the ocean, one category- 4 moved close to the peninsula. None of these systems made the widespread impact that the approach of TC Juliette, in late September 2001, had over the Sierra La Laguna (SLL, Fig. 1) mountains. The events associated with TC Juliette are therefore chosen to illustrate the occurrence of landslides in this region of southwestern North America.

Tropical cyclone Juliette moved during several days in a path a few hundred kilometers west of the southern peninsula (Ávila et al., 2003), bringing record rainfall to some areas in the region (Farfán, 2004), and generating geomorphic and ecosystem effects that disrupted importantly 

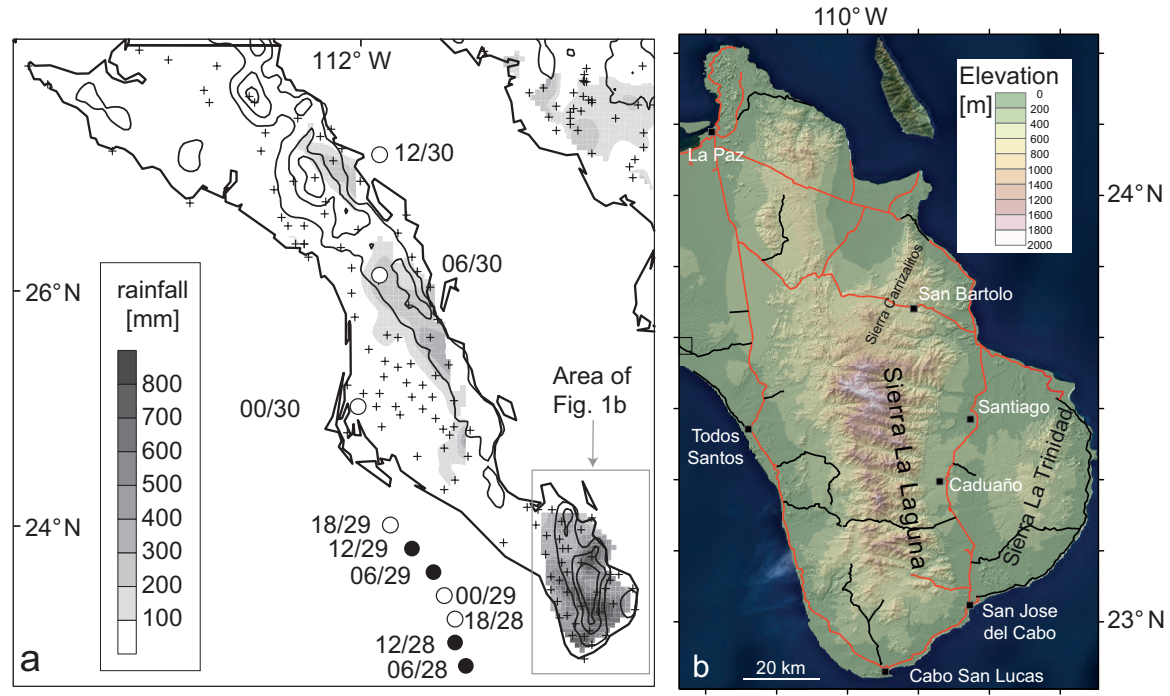

Fig. 1. Tropical cyclone Juliette approach to the southern Baja California peninsula. (a) Storm best track according to NHC records shown with dots (closed: hurricane; open: tropical storm and tropical depression), presenting accumulated storm rainfall in $\mathrm{mm}$, with intervals displayed in the sidebar. Contours for terrain elevation (solid lines) at 300,600 and $900 \mathrm{~m}$. Plus signs indicate meteorological stations with daily observations that were used to prepare the figure. Time indicated is UTC/day. (b) Shaded relief map showing elevation at the $200 \mathrm{~m}$ interval for the southern tip of the Baja California peninsula (note the location of the Sierra La Laguna).

human activities (e.g., Ávila et al., 2003; Martínez-Gutiérrez and Mayer, 2004; Camacho-Valdez et al., 2008). However, there is no documentation referring to widespread landsliding in the southern SLL as a result of its approach. Landslide occurrence may be considered rare because it is documented for the first time. However, on a historical perspective, it is not the first landslidetriggering event that has occurred, and not the last. We describe here for example a 1907 storm that generated landslides, and also landslides occurring on landfall of more recent TCs. This paper reports the landslides associated with TC Juliette, characterizing them and assessing the conditions of antecedent and accumulated storm precipitation, geology, geomorphology, slope aspects, soils and vegetation. We discuss the relevance and recurrence of these landslide events as first-order surface processes controlling erosion in the southern peninsula, with implications for other arid and semi-arid regions subject to highly seasonal rainfall.

\section{Data and methods}

The geographical area of interest includes the SLL mountainous region, with mean elevation above $600 \mathrm{~m}$ and maximum altitudes reaching 1500-2000 m, increasing from south to north. To identify the landslides that occurred during the approach of TC Juliette to Baja California on September 27-30, 2001, we used two Landsat 7 TM images taken before (May 19) and after (October 26) its landfall. Primary information obtained from the satellite imagery at $\sim 30 \mathrm{~m}$ resolution was corroborated using aerial photographs from Mexico's Instituto Nacional de Estadística, Geografía e Informática (INEGI, http://www.inegi.org.mx), some of them orthorrectified, for dates before 
and after the event, and taken at scales between 1:70 000 and 1:40 000. Quickbird $\AA$, Geoeye ${ }^{\circledR}$, and SPOT ${ }^{\circledR}$ orthorrectified satellite imagery at $\sim 5-10 \mathrm{~m}$ resolution was also used to digitize at 1:25000 scale the landslide inventory, to estimate scar areas and triggering points, and to follow the temporal evolution of some of the landslides after 2001. Digital elevation model (DEM) information was obtained from SRTM90 (http://srtm.usgs.gov) datasets and from regional DEMs from INEGI, which were used to extract secondary topographical features like relief at $5 \mathrm{~km}$ radius, local slope and aspect. We not only used visual identification of landslides with the imagery from band combinations like RGB 453 or 742 but also band ratios (e.g., TM5/4, TM5/7) to reduce brightness effects associated with topographic slope and aspect effects (e.g., Restrepo and Alvarez, 2006). All information was processed and compiled in ARC $($. Terminology used to classify the landslides follows Cruden and Varnes (1996). Field reconnaissance was performed during late 2010 and early 2011 to assess the extent of visible landslide scars and deposits ten years after the event. Most of the field-checked deposits $(\sim 20)$ are located in lower, accessible areas portraying landslides (e.g., the San Dionisio area).

We focused our analysis in the relevance of landslides as a sediment production process, and not in the extent of the final deposit. The mapping therefore reflects areas of failure origin, rather than full trajectories of debris flows or slides. Most of the flows were aggregated into higher order channels very close to the origin and no attempt was made to map the extent of the flows beyond third order channels. Limitations of the mapping approach include the difficulties associated with locating the transitional zone between scar and depositional lobes on the imagery for most shallow slips, and the transition area between these slips and downslope debris flows. The few field measurements of linear distances in the field compared to the GIS estimates on the same landslides yield differences of up to $5-10 \%$, depending on factors like imagery resolution, slope values unaccounted for, and revegetation obscuring boundaries of scar regions and original slopes. All measurements used to calculate landslide dimension are considered as having $10-20 \%$ uncertainty (areas and volumes, by adding in quadrature possible errors from each), and in agreement with previous reports for landslides in other regions (Antinao and Gosse, 2009).

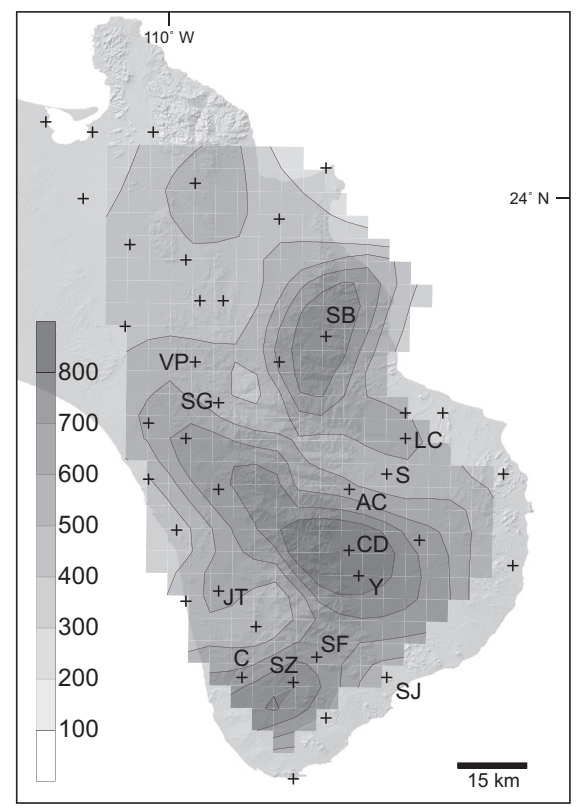

Fig. 2. Tropical cyclone Juliette accumulated storm rainfall for the southern tip of the Baja California peninsula. The distribution of accumulated precipitation in $\mathrm{mm}$ is derived from the operational network of surface stations in BCS, with data from September 26-30, interpolated onto a uniform grid using the Barnes objective analysis (Koch et al., 1983). Even though the spatial distribution of the available stations is not uniform, the interpolated grid is useful for a visualization of the activity that was associated with the passage of TC Juliette. Key for the stations mentioned in Figure 3: Santiago: S; Las Cuevas: LC; Agua Caliente: AC; San Bartolo: SB; Valle Perdido: VP; Santa Gertrudis: SG; San Jacinto: JT; Caduano: CD; Yenecá: Y; San José del Cabo: SJ; El Sauzal: SZ; San Felipe: SF; and Candelaria: C. 
To study the trajectory and impact of TC Juliette, several datasets were used. GOES infrared imagery was used to assess the cloud-cover structure. Precipitation was obtained from the daily data of the network managed by the Comisión Nacional del Agua (Conagua, Mexico) (Fig. 2). This network was also used to assess the contribution of antecedent rainfall in the observed slope failures. High temporal resolution $(10 \mathrm{~min})$ wind and rainfall data were obtained from an automated station at Cabo San Lucas (Fig. 1). This station, unfortunately, malfunctioned during the second half of the storm passage, as the winds exceeded $122 \mathrm{~km} / \mathrm{h}$, impeding the rest of the event to be recorded, probably because the gauge was damaged. Stream discharge data (Conagua) for catchments originating at the SLL were not available during 2001, but we used previous records from another TC (1982) to describe and assess the potential relevance of stream discharge in removing landslide sediment.

\section{Results}

\subsection{Rainfall associated with tropical cyclone Juliette}

The first stages of Juliette were just off Central America and, while intensifying, the hurricane moved parallel to the Mexican coast to reach category-4 strength on September 24. Later, it weakened and followed northward motion to approach Baja California. Key meteorological parameters indicate that Juliette was an intense storm, delivering an extremely large amount of precipitation to the southern peninsula (Fig. 2). Note that few stations are located over $500 \mathrm{~m}$ (Fig. 1). The area with most relevant rainfall was the SLL range, with several stations in the vicinity or along its edges reporting more than $750 \mathrm{~mm}$ accumulated in at least three days. These stations tend to be located along the southern or eastern side of the range (Farfán, 2004). A maximum of $1011 \mathrm{~mm}$ was reported at Caduaño (30 km north of San José del Cabo, Fig. 2) where more than $200 \mathrm{~mm} / \mathrm{d}$ were received during three consecutive days. Another area of maximum rainfall can be observed over a mountain range located between $25-27^{\circ} \mathrm{N}$ with $250-500 \mathrm{~mm}$ (Fig. 1). In contrast, limited rainfall was reported from stations in the central peninsula.

\subsection{Antecedent rainfall during 2001}

We compiled information for antecedent conditions for the stations that recorded rainfall during the TC approach. No significant precipitation was found prior to the storm, during the period January-September 2001. The time series of monthly rainfall (Fig. 3) at stations located in the eastern slopes of the sierra (Fig. 2), close to where most landslides occurred, show that most of the period's precipitation was collected in September and most came from the previous five days (26-30), when Juliette approached the peninsula. The time series at Caduaño (Fig. 4) shows no significant accumulation in the preceding months, with weaker storms affecting the area every 8-10 days, averaging $20 \mathrm{~mm}$ per event. Similarly, the stations located on the southern and western SLL show no accumulated rainfall previous to the TC passage (Fig. 3).

\subsection{Landslides}

Satellite imagery and aerial photography were compared before and after the TC passage. A total of 419 landslides (Table I) were identified in the hillslopes of the southern SLL (Fig. 5), within 

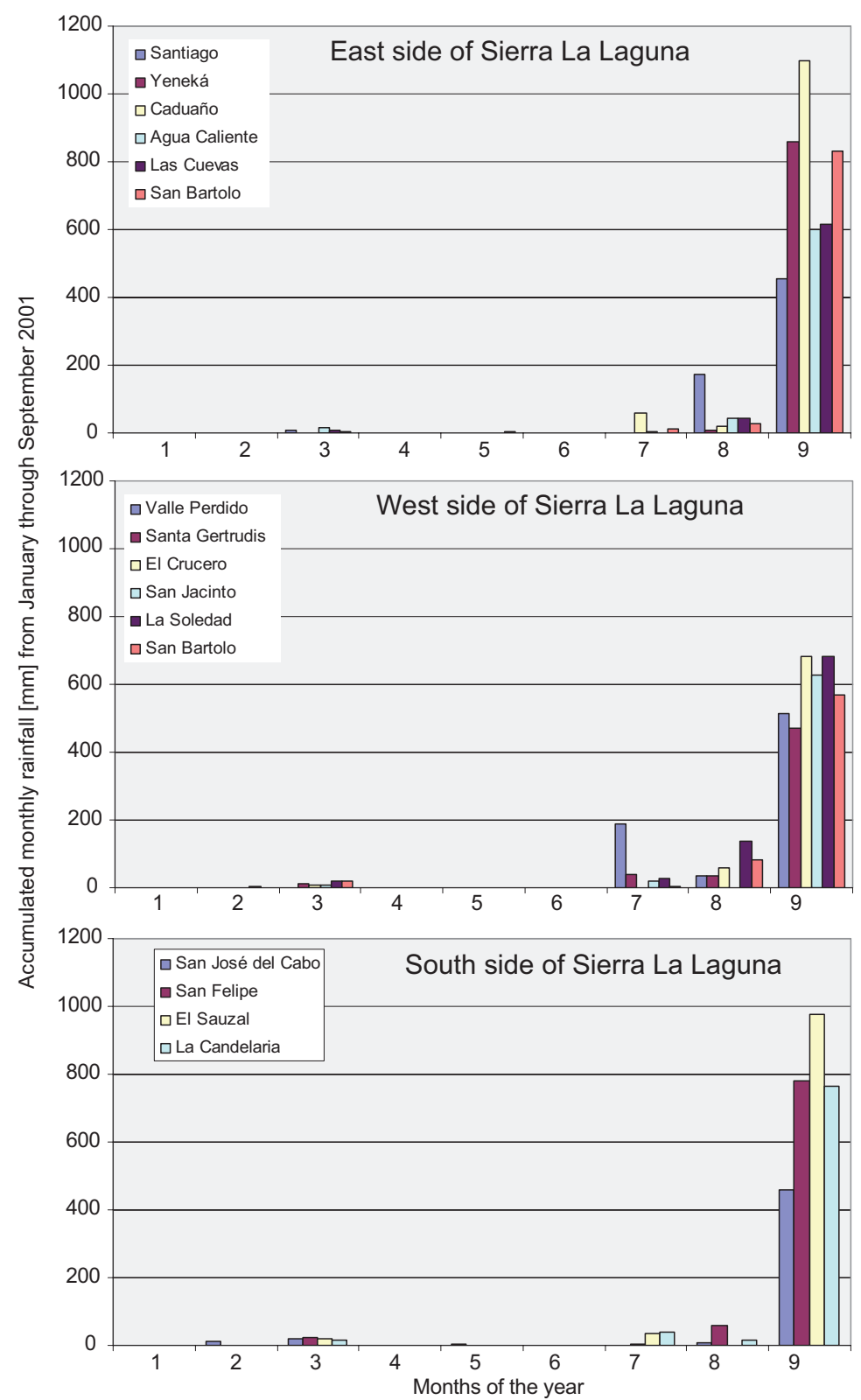

Fig. 3. Accumulated monthly rainfall time series for stations located in different areas in relation to the mountains of Sierra La Laguna. Precipitation in $\mathrm{mm}$. Location of stations in Figure 2. Numbers along the horizontal axis denote months of the year.

an area of $\sim 1000 \mathrm{~km}^{2}$. Additionally, we identified nine landslide scars generated before that date, and eight other landslides that occurred probably during 2003, both of which will be discussed later. Geographically, a clear separation appears between two zones of higher landslide density. A northern zone occurrs along the La Zorra, Boca de la Sierra and Portezuelo catchments. A southern zone appears mainly along the San Lázaro and San Miguelito catchments (Fig. 5; Table II). 


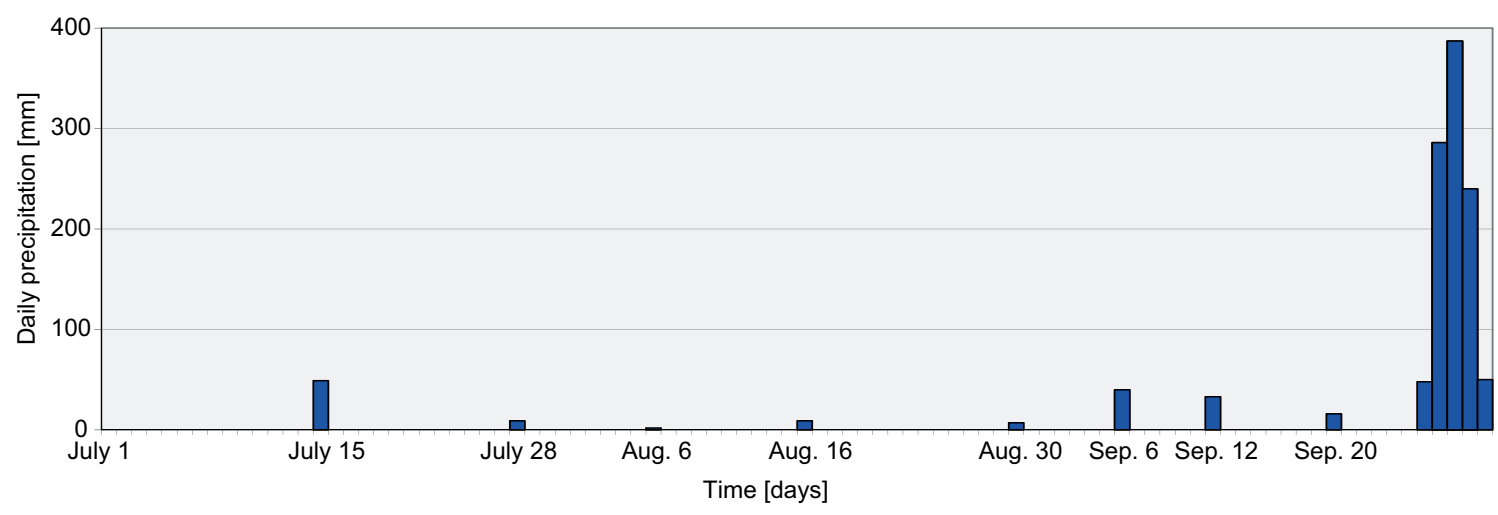

Fig. 4. Time series of daily rainfall at Caduaño for the period July-September 2001. Main storm events are labeled in the horizontal axis.

Table I. General properties of the landslide inventory.

\begin{tabular}{lc}
\hline Number of landslides & 419 \\
\hline Area mapped $\left(\mathrm{km}^{2}\right):$ & 990 \\
$\quad$ Total area scanned & 821 \\
$\quad$ Total area of catchments assessed individually & 2408 \\
\hline Average landslide size (area in $\left.\mathrm{m}^{2}\right)$ & \\
\hline Proportion of total area in the inventory (\% of total) contributed by landslides: & \\
$\quad$ Larger than $1000 \mathrm{~m}^{2}$ & 2.5 \\
$\quad$ Larger than $10000 \mathrm{~m}^{2}$ & \\
\hline Largest area ( $\left.\mathrm{m}^{2}\right)$ landslides: & 15000 \\
$\quad$ Boca de la Sierra 1 & 14920 \\
$\quad$ Boca de la Sierra 4 & 18550 \\
$\quad$ Portezuelo 20 & \\
\hline Largest run-out (km) landslides (resulting debris flows): & 2.3 \\
$\quad$ Portezuelo 20 & 2.3 \\
$\quad$ San Lázaro 1 & \\
\hline
\end{tabular}

Note: Landslides names refer to those reported in the supplementary data files.

Most landslides occurred in the south facing, upper portion of slopes. Shallow soil slips and debris flows were the predominant forms of slope failure. The shallow slips that were checked in the field seem to originate from failure planes near the soil-saprolite or soil-bedrock boundary, approximately 1-2 m deep. Most of the debris flows can be traced upslope to shallow soil slips with failure planes similarly located in the soil-saprolite or soil-bedrock boundary, although some of the debris flow scars appear immediately downstream of bedrock exposed surfaces. Most of the landslides initiated near the top of the hillslope, and then traveled towards the closest drainage channel. At this stage, at least a third order channel was reached, and most slides evolved there into debris flows, indicated by the scars left (Fig. 6) on the hillslopes and channels. Some of the largest landslides were more than $500 \mathrm{~m}$ long and 30-40 m wide (scar dimension), and subsequent flow paths were $\sim 1-2 \mathrm{~km}$ long (Table I). Even the largest deposits (e.g. San Lázaro and PortezueloAncón Grande, Fig. 6) did not preserve a debris lobe after the TC passage, which indicates a very 


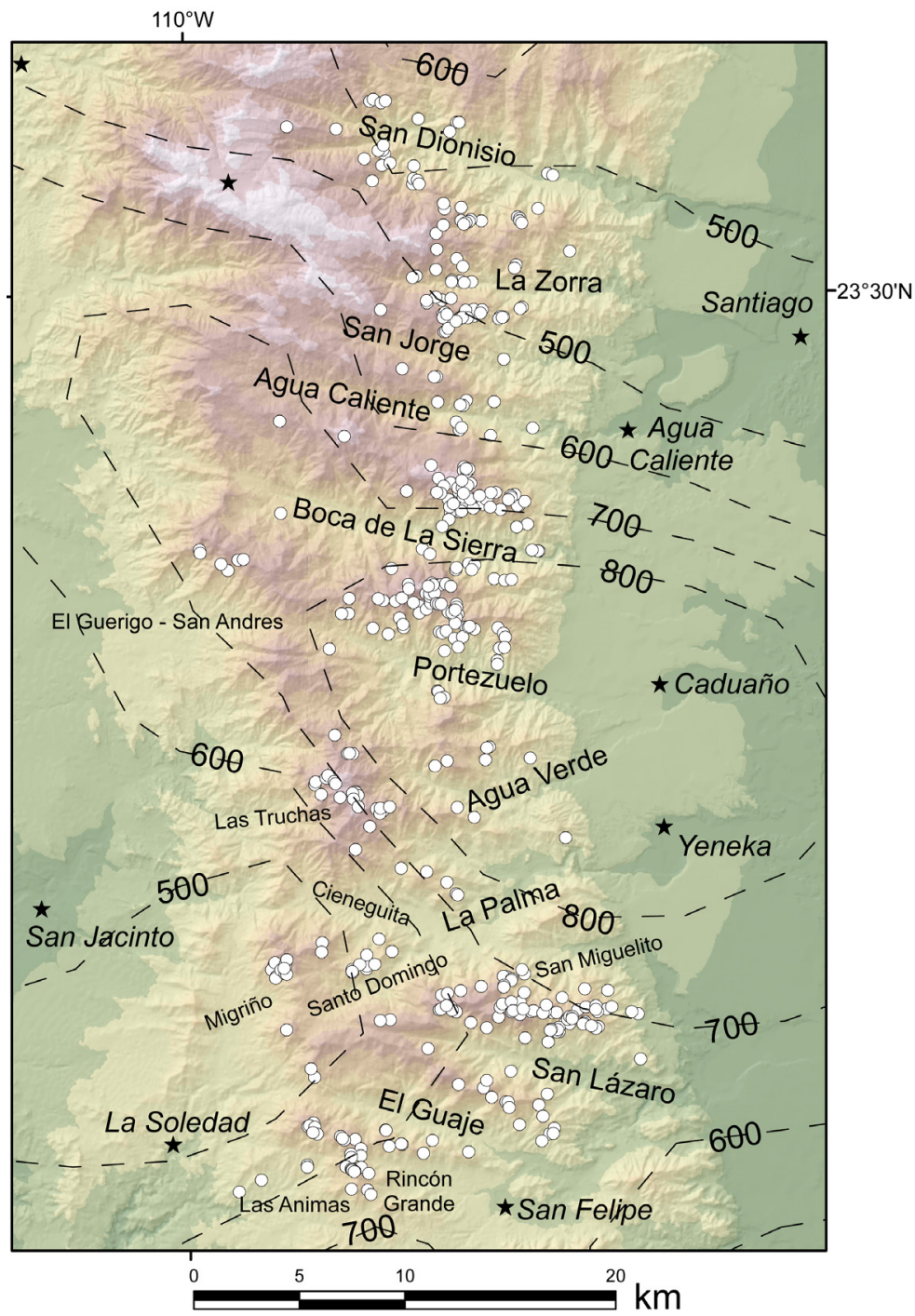

Fig. 5. Spatial distribution of landslides. Individual catchments mentioned in the text are labeled. Stations marked with stars and labeled were used to estimate precipitation through interpolation in areas between them (Fig. 2). Unlabeled stations did not record. Elevation intervals are the same than in Figure 1. Note that most stations are located at elevations lower than $500 \mathrm{~m}$ and that orographic effects on precipitation are not taken into account by the method of interpolation used.

rapid removal of the sediment in the channel. No indication of dammed streams appears along the channels, suggesting that stream power was enough to absorb and transport all landslide sediment downstream. 


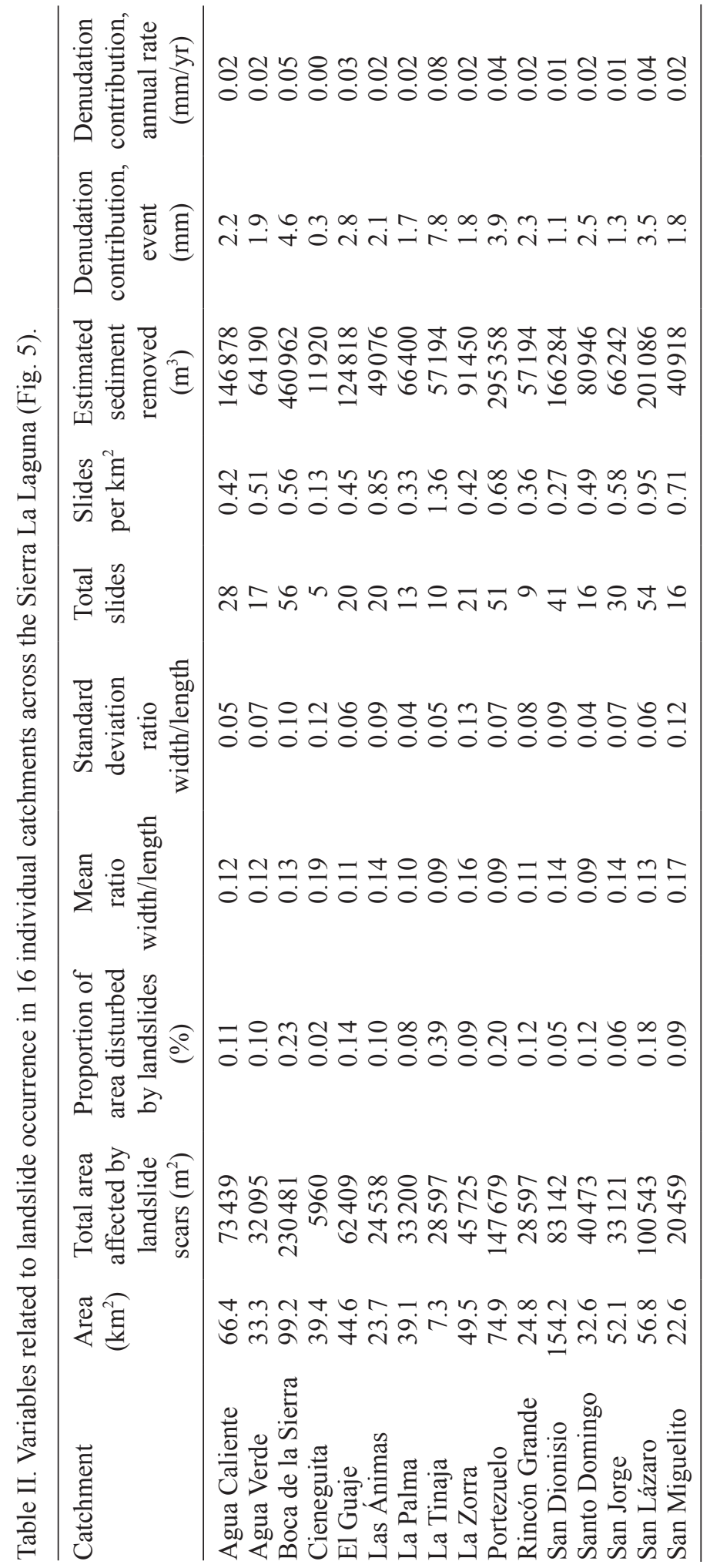



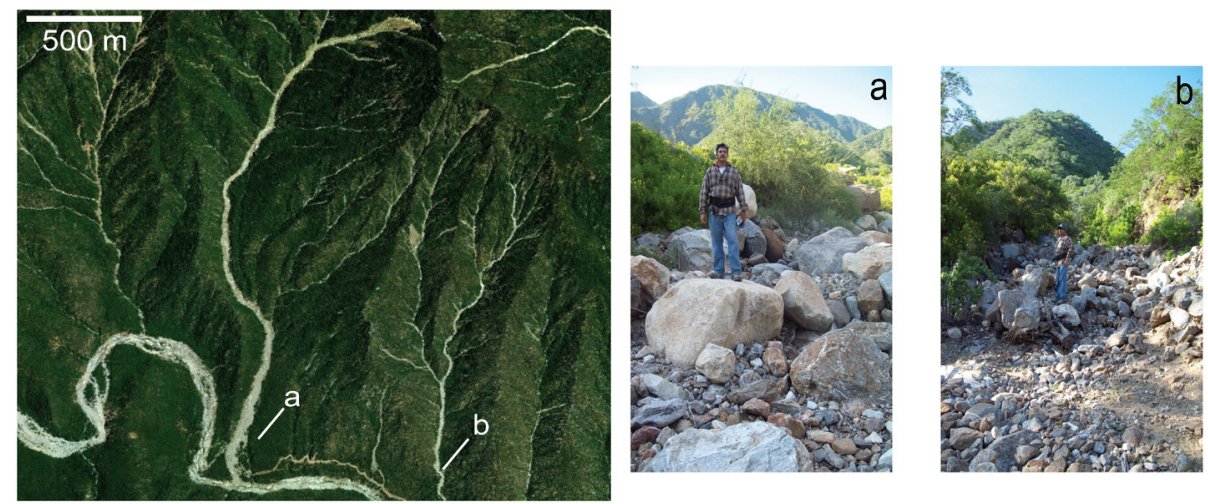

Fig. 6. Debris flow deposit remains on two channels in the Portezuelo-Ancón Grande catchment. Main panel shows extent of the landslides in this area. Main channel bed elevation ranges from $460 \mathrm{~m}$ in the left to $360 \mathrm{~m}$ at the lower right portion of the image. Highest ridges at the top of the image display elevations of $\sim 1200 \mathrm{~m}$. Note other shallow slips and debris flows paths originating from the ridges in the upper portions of the image. Date of GeoEye ${ }^{\circledR}$ imagery: 2005. (a-b) Ground views of the lower portions of the debris flows paths shown in the image. Mostly metamorphic rock boulders (1-2 $\mathrm{m}$ in diameter) remain in the streambed, and finer grain size sediment has been stripped. Date of ground photographs: 2011.

\section{Assessment of potential conditioning and triggering factors}

In the following subsections, we contrast the spatial distribution of landslides against the distribution of different factors that may condition or trigger slope failures.

\subsection{Antecedent and storm rainfall}

Comparison of landslide triggering points and total accumulated rainfall isohyets indicate that most of the landslides are located in a region bounded by the $600 \mathrm{~mm}$ contours (Fig. 5). The northern landslides appear in areas where interpolated total precipitation is apparently less than $500 \mathrm{~mm}$, with the caveat that at least three stations in the northwestern SLL were not reporting at the time of Juliette's approach. Note the lack of high (>500 m) elevation stations between Caduaño and the SLL western slopes that could be used in assessing rainfall distribution in this rugged topography. No landslides were observed under a northern band of high $(\sim 800 \mathrm{~mm})$ accumulated rainfall along Sierra Carrizalito (Fig. 1) centered at San Bartolo (Fig. 2), in a northern extension of the SLL.

Most of the landslides are clustered along the eastern SLL (Fig. 5), which correlates with the higher precipitation accumulations observed in this area (Figs. 2-5). This fact indicates that the event precipitation and associated runoff are probably the main factors responsible for slope failure. This interpretation is supported also by the lack of correlation between antecedent rainfall (Fig. 3) and landslide location, which indicates that previous summer precipitation was not a factor in triggering the slope failures.

\subsection{Geology}

The SLL geology is composed predominantly by Late Cretaceous granites and granodiorites intruded into Early Cretaceous granodiorites, tonalities and diorites (Consejo de Recursos Minerales, 2002, 

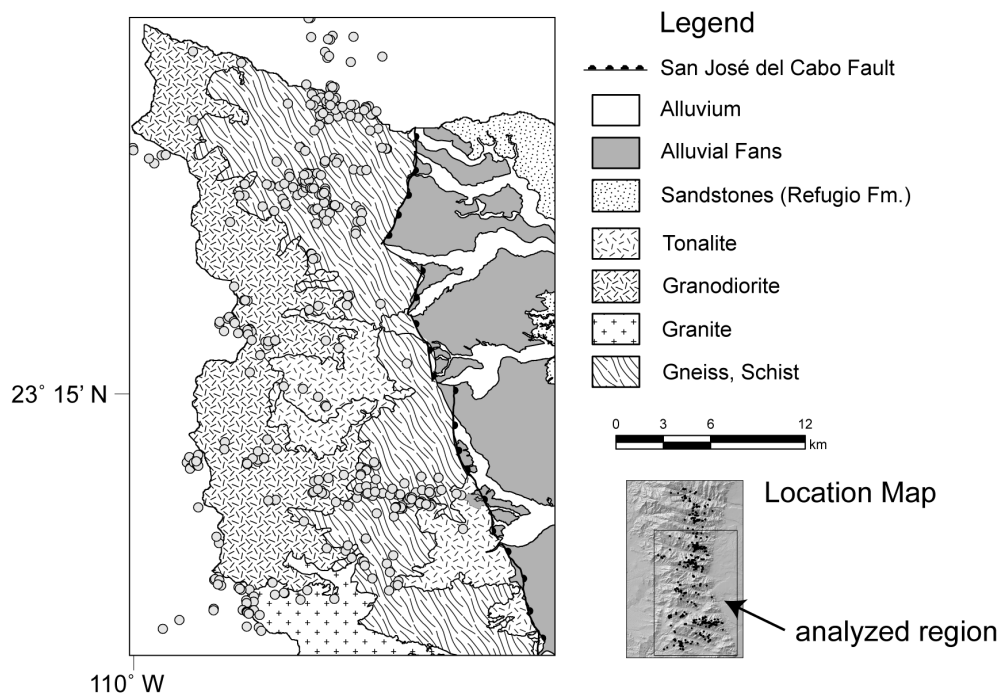

Fig. 7. Spatial distribution of the central and southern landslides in the SLL compared to the distribution of geological units. Geological map according mostly to Martínez-Gutiérrez et al. (2010), at 1:50 000 scale. Blank areas to the north and west display undifferentiated granitic rocks according to Consejo de Recursos Minerales $(2002,2008)$ at scale 1:250000 and therefore the area chosen for the figure covers a smaller, more detailed zone than the whole area covered by the study (see location map), in order to highlight possible linkages between failures and geology.

2008; Martínez-Gutiérrez et al., 2010), the latter outcropping mostly along the western side of the range (Fig. 7). Jurassic metasediments, mostly schists, phyllites and gneiss appear in slivers in the eastern side, intruded by the granitic rocks. The granites and granodiorites are affected by brittle and ductile deformation in the southeastern portion of the range, near San José del Cabo. Geological structures define a characteristic pattern of ESE-WNW valleys in the southern and eastern portions of the Sierra, while in the northwestern sector a NW-NNW pattern associated with the La Paz fault, a regional structure, is predominant. Field observations and analysis of the drainage network (e.g., Martínez-Gutiérrez et al., 2010) indicate that the fracturing pattern and its expression in the drainage pattern differ between these two regions, with a well defined dendritic pattern in the northwest SLL, versus a subparallel or trellis drainage pattern in the southeast. These patterns are controlled by fractures, dikes and fault systems, but also by lithology: dendritic patterns predominate in granitic rocks while sub-parallel and trellis patterns predominate in the metamorphic rocks to the southeast.

After considering the proportion of area covered by the different lithologies (Fig. 7), landslides appear to correlate to areas of predominantly metamorphic (gneiss and schists) and granitic lithologies displaying brittle deformation. This correlation is evident when comparing the largely granitic round-shaped catchments of La Palma and Agua Verde with the ENE elongated, schistgneissic dominated San Lázaro, Portezuelo and Boca de la Sierra catchments. Faults and foliation do not appear to dictate a priori landslide location, but they strongly dictate slope and drainage orientation, as in the Portezuelo and San Lázaro catchments (Fig. 8). 

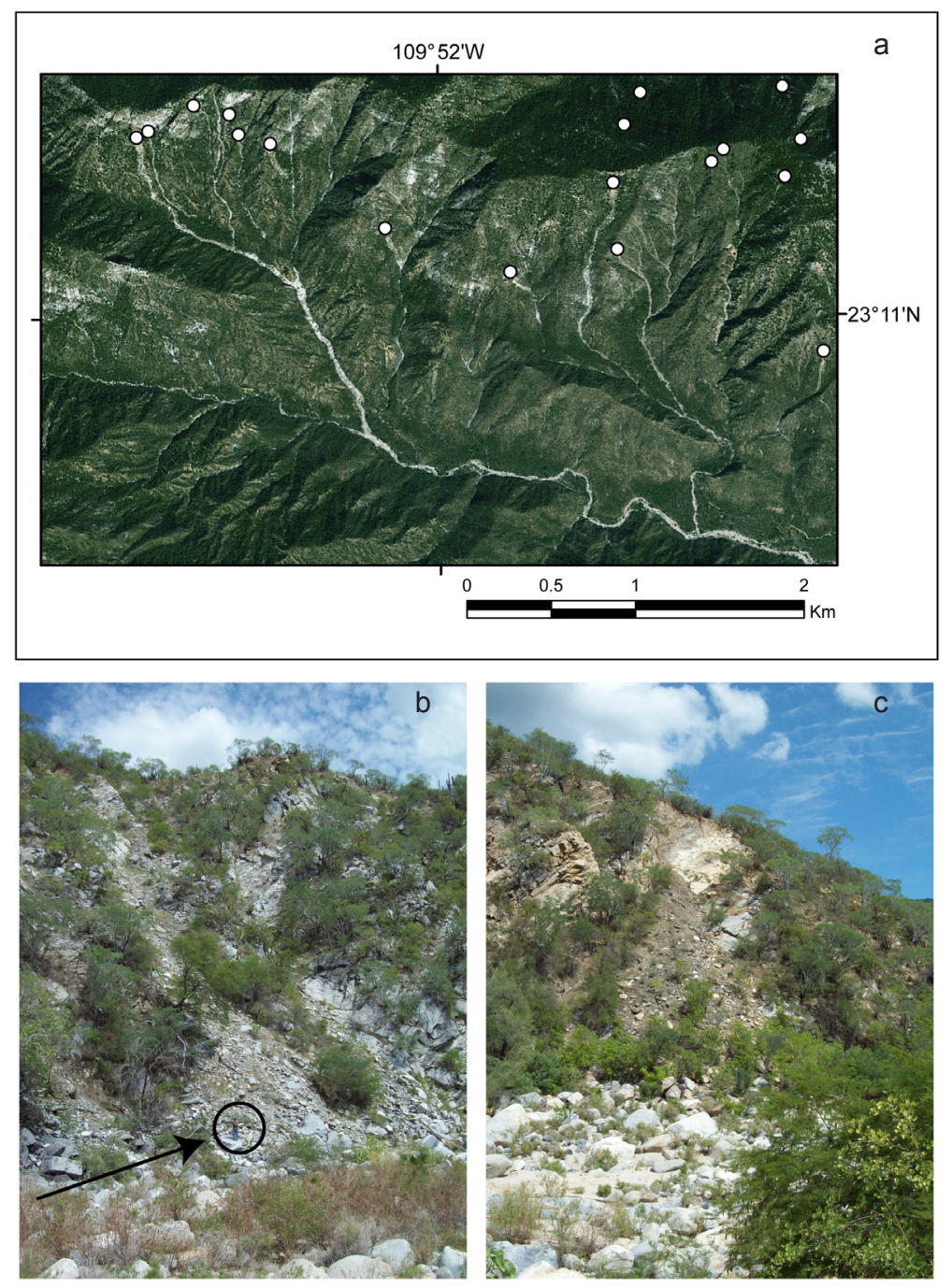

Fig. 8. Images illustrating the influence of faults and fractures on shallow slides in the study area. (a) 2010 SPOT ${ }^{\circledR}$ image showing location of TC Juliette-related landslides (circles indicate estimated triggering points) in relation to a WNW fault in the San Lázaro catchment. Failures are located on the hanging wall, on the north side of this structure. (b-c) Small, probably post-2001 rockslides in the lower San Dionisio catchment. Note geologist on the debris lobe of the deposit in (b), and the planar bright surface in (c) suggesting that an entire wedge of rock failed following this structural feature. Date of ground photographs: 2011.

An indication of the possible role of fracturing in controlling the slides is given by the spread in the population of width to length ratios of landslide scars (Table II). The spread is lower in catchments where fracturing is homogeneous and pervasive, as in the granitic-tonalitic areas (e.g., La Palma and Agua Caliente catchments). In the regions where heterogeneous fracturing dominates (e.g., foliation and metamorphic structures), like San Dionisio, La Zorra and Boca de la Sierra in the north, and San Miguelito in the south, the ratios display more spread. The 

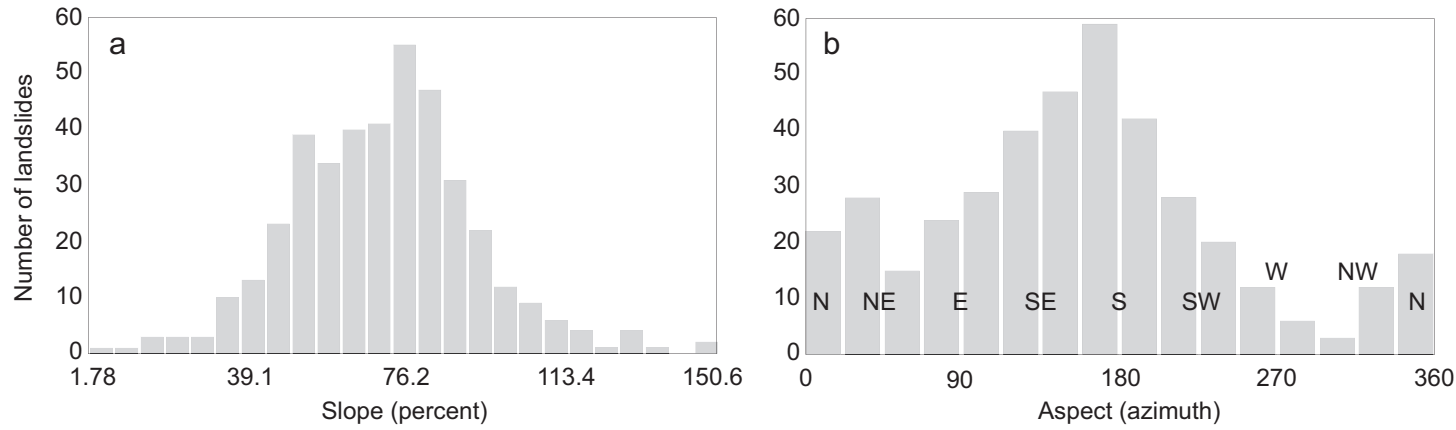

Fig. 9. Slope and aspect frequency distribution of landslide inventory. (a) Slope. (b) Aspect.

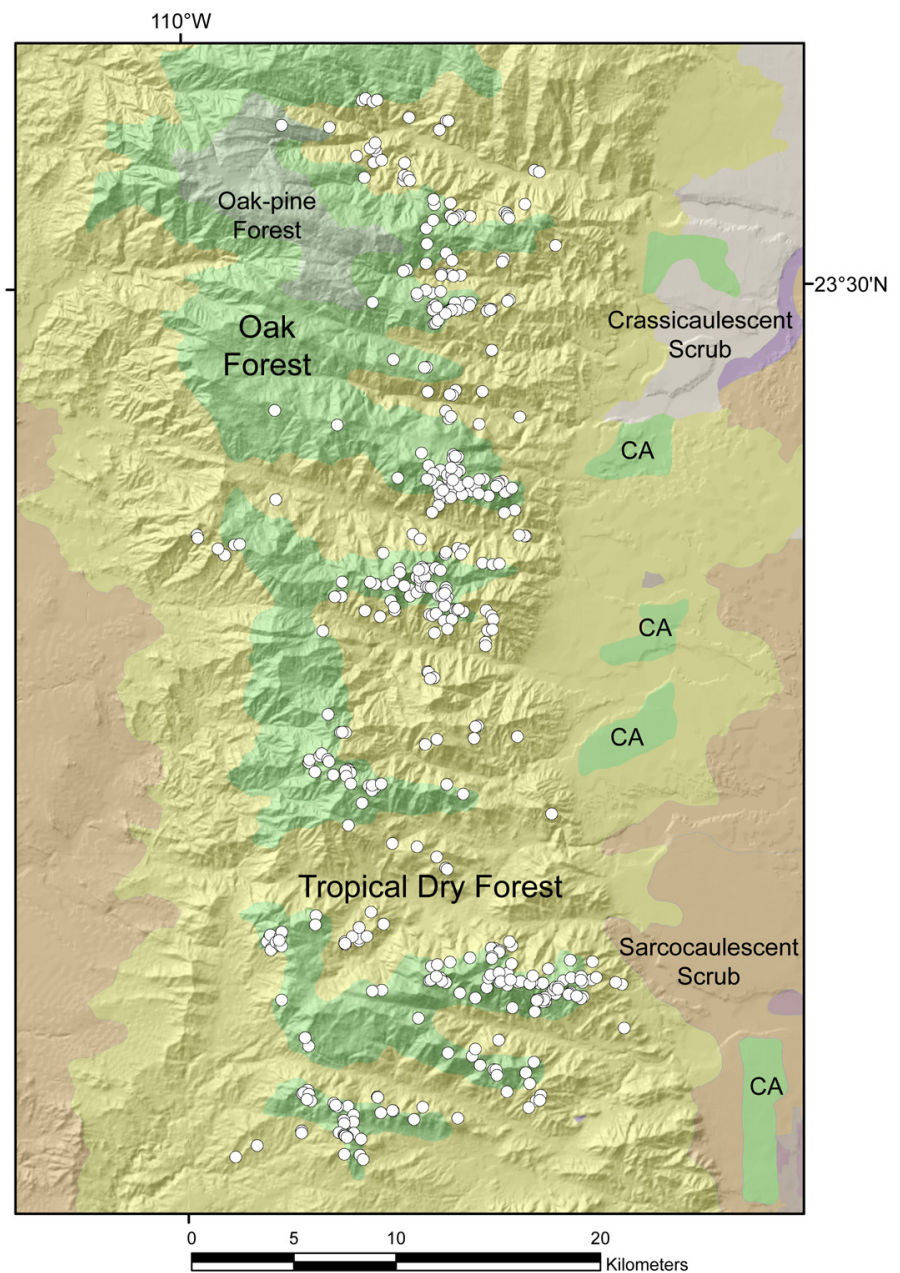

Fig. 10. Spatial distribution of landslides vs. predominant vegetation association (INEGI, 2005; León-de la Luz and Domínguez-Cadena, 2010). CA refers to cultivated areas, with some irrigation. Note that vegetation types roughly follow altitudinal zones (compare to Figs. 1 and 5). 
latter indicates that scar dimensions in these regions are constrained by the fracturing pattern and spacing. This is ratified in the field, as some of the landslides clearly display removal of material in wedges of rock between fractures (Fig. 8c).

\subsection{Slope and aspect}

More than $90 \%$ of failures initiated along slopes of $\sim 44-122 \%\left(23-50^{\circ}\right.$, Fig. 9$)$, with a mean around $35^{\circ}$. The slope distribution (Fig. 9) is broad, indicating that slope is not the main factor, and that other modulating factors are influencing the distribution of slides across hillslopes. For more than $90 \%$ of failures the geometrical center of the initial detachment area is located in the upper third of the slopes; a similar figure is obtained when comparing slide initiation points and aspect of the slope (most failures occurred on SE or S slopes, Fig. 9).

\subsection{Vegetation}

The vegetation in the area is dominated by subtropical dry and oak forests generally above 150-300 and 800 m, respectively (INEGI, 2005; León-de la Luz and Breceda, 2006; León-de la Luz and Domínguez-Cadena, 2010). In areas below $150-300 \mathrm{~m}$ a sarcocaulescent desert scrub association is found. Notably, most landslides correlate spatially with oak forests or with the location of the ecotone between oak forests with the subtropical dry forest, with very few landslides in the latter unit (Fig. 10).

\subsection{Soils}

Field observations in the northern (San Dionisio) and southeastern portions of the study area (San Lázaro) indicate that over most hillslopes, fractured bedrock appears covered by a thin $(\sim 1 \mathrm{~m})$ veneer of rock fragments, and tree and shrub roots penetrate deeply into the fractures to affix themselves to the rocky substrate. Soils therefore are shallow, with variable depths between a few centimeters and 1-2 $\mathrm{m}$ of developed profile above regolith or bedrock, with deeper profiles on the banks along major streams. Soils in the area can be classified as eutric regosols to chromic cambisols (INEGI, 2007) in the southern portion (San Lázaro), varying to eutric regosols and lithosols in the central and northern SLL (e.g., San Dionisio canyon, Fig. 11). Almost all landslides appear to be developed in areas displaying eutric regosols along the catchment uplands, indicating that soils are not a controlling factor in the failures.

\section{Discussion}

We have documented the occurrence of hundreds of failures resulting from the approach of TC Juliette to the southern Baja California peninsula. In the next paragraphs, we analyze triggering factors and antecedent conditions favorable to failure development, both introduced in section 4, and conclude estimating possible recurrence of a similar event from the analysis of historical information.

In order to validate our analysis, we assessed whether the landslide inventory obtained a decade after the storm occurred is representative of the original slope failures. We are confident that the landslide inventory reflects very accurately slope failures for two reasons. First, the area-frequency graph (Fig. 12) still shows the characteristic shape of inventories prepared immediately after triggering by rainfall, characterized by a heavy-tailed distribution (e.g., Larsen 


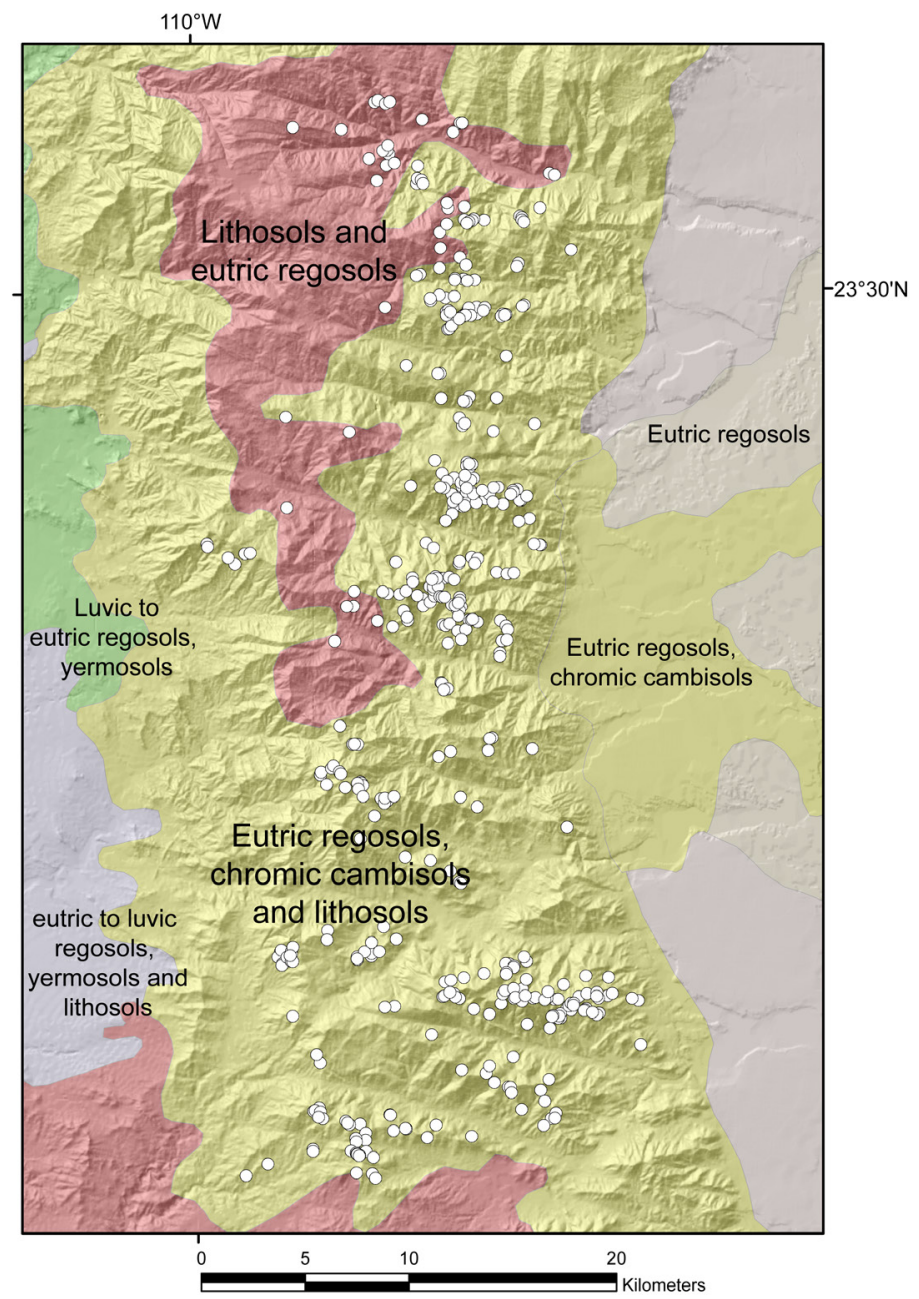

Fig. 11. Spatial distribution of landslides vs. soil types.

and Torres-Sánchez, 1992; Malamud et al., 2004). Second, estimated revegetation rates (Fig. 13) appear to be slower than suggested for some tropical humid environments (Crone et al., 2001). Revegetation rates might be more similar to the ones estimated for semiarid to temperate slopes affected by similar shallow slides, where failures can still be seen after five (Webb et al., 2008) or ten years (Hovius et al., 2000).

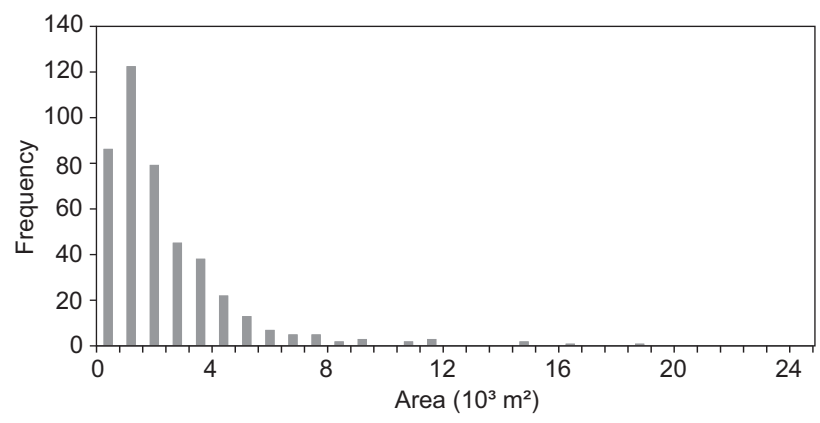

Fig. 12. Area-frequency diagram for the TC Juliette landslide inventory. 


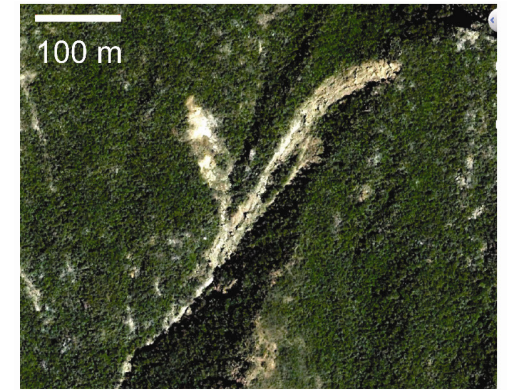

20041005

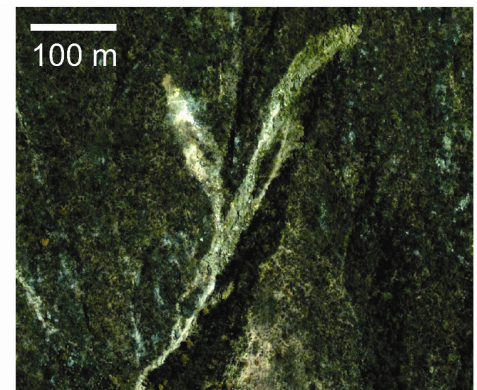

20060418

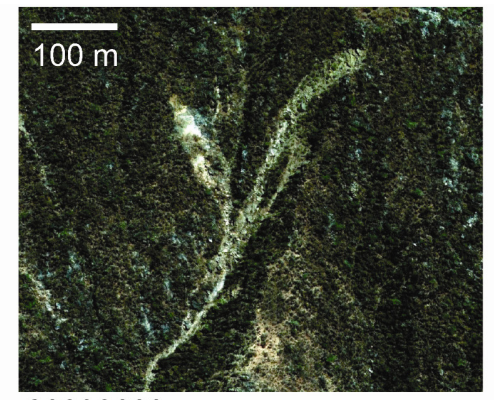

20090609

Fig. 13. GeoEye ${ }^{\circledR}$ imagery illustrating revegetation sequence for a pair of TC Juliette derived landslides in the San Lázaro catchment between 2004 and 2009. Dates in format YYYYMMDD.

\subsection{Mechanisms of slope failure}

The more than 400 landslides triggered by Juliette represent a unique opportunity to study the natural processes that generate slope failures in a relatively undisturbed subtropical, semi-arid landscape. Across the entire study area, landslides were mostly shallow, upper slope failures, and the involved soils and debris were transformed rapidly into debris flows that later were incorporated into the stream flow.

\subsubsection{Conditioning of slopes}

Necessary conditions for the occurrence of failures are the incidence of steep slopes $\left(>22^{\circ}\right)$, combined with a geological substrate with developed fracture systems that focused infiltration to specific areas in the landscape. A relationship with vegetation types, although less clearly defined, is possible, however more detailed site information is needed to clarify this potential linkage.

The spatial distribution of failures supports a heterogeneous distribution of rainfall intensities and amounts derived from Juliette across the SLL, confirming observations for more humid tropical settings (Galewsky et al., 2006). The wind flow in the eastern storm quadrants was responsible for the higher proportion of S-SE facing slopes portraying landslides. Orographic lifting of moist air across the entire sierra in an EW transect is observed in the differential rainfall developed for the eastern and western sections of the range, which is strongly correlated with landslide occurrence.

\subsubsection{Triggering mechanisms}

The predominant landslide occurrence in the upper portion of slopes indicates that surface infiltration of rainfall in the higher elevation portion of the hillslopes was not enough to cope with runoff from the high rainfall intensity derived from the storm. It is estimated that rapid saturation (i.e., hours) of the upper 1-2 $\mathrm{m}$ of soil and fractured bedrock increased the pore pressure in the loose regolith on the steep slopes. The regolith started mobilization by gravity in these conditions and, under the relatively long duration (24-36 h) intense precipitation, overland flow developed, carrying away finer portions of the sediment, finally removing support for larger blocks derived from tectonic fracturing of the upper slopes. In a later stage, larger ( $>5 \mathrm{~m}$ diameter) blocks of bedrock were left free to be also mobilized by gravity, carrying in their fall remaining soil and vegetation attached 
to them. Probably, not all slopes reached this stage as large boulders are still recognizable dotting some of the original scar areas.

The general pattern described above can be considered valid for most of the failures, although it is possible to identify and characterize more precisely two types of slope failures related to the TC approach: those triggered by overland flow enhancement, and those related to disturbances on the upland SLL forests.

A. Overland flow triggered debris flows and shallow slips. For an important portion of the landslides, failures occurred immediately below areas of exposed bedrock, in the upper third of the slopes. The corresponding mechanism appears to be related to generation of excess overland flow impacting semiconsolidated colluvium, as reported in other semiarid mountain settings (e.g., Griffiths et al., 2004; Webb et al., 2008; Coe et al., 2008). Although the SLL displays more vegetation, including arboreal species not present in the regions above described, concentration of runoff at the end of upper slope ravels or at the foot of bedrock cliffs had probably the same "fire hose" effect (e.g., Johnson and Rodine, 1984) described in those regions. This mechanism requires streamflow over a waterfall on preexisting colluvial wedges at the base of cliffs, causing failure and subsequent mixing to create a slurry ( $c f$. Griffiths et al., 2004). Relatively scarce understory cover in the tropical dry and oak forests in these catchments (León-de la Luz and Breceda, 2006) might be responsible for this effect. Once the initial portions of the surface sediment are mobilized, they displace downslope, either eroding and incorporating more sediment into a debris flow, or entering into a first or second order channel. The sediments may be later removed by action of a subsequent debris or channel flow. Our field observations indicate that this removal may be strongly dependent on the original triggering mechanism. If overland flow was involved, as hypothesized for the debris flows in the San Lázaro catchment, streambeds tend to remain free of sediment. In other cases, large boulders are left as a lag deposit (Fig. 6).

B. Forest disturbances triggering slope failures. A portion of landslides, particularly those associated with the ecotone oak-tropical dry forest, were initiated in areas of convex or planar topography. In these landslides, apparently concentration of runoff in colluvial hollows or by upslope bedrock channelization was not a relevant process. Some of these areas should have been largely exposed to high winds near ridges in the southern and eastern facing slopes. We interpret these slope failures as occurring in areas of enhanced precipitation caused by topographic lifting coupled with high rates of uprooted trees caused by high winds ( $c f$. Arriaga, 1988), causing both immediate regolith disturbance and increasing bare areas that enabled runoff concentration. A potential differential response to high winds between the oak forest and the tropical dry forest is not possible to assess with the available data, because detailed mapping of forest structure, canopy cover, tree mortality, etc., was unfeasible under the scope of this study.

Triggering of landslides by disturbance of the vegetation is not uncommon in upland areas affected by TCs (e.g., Larsen and Torres-Sánchez, 1992) or in other forested environments (Millard, 2003). This fact highlights the large effects of topography in the spatial distribution of rainfall and wind, both of which will eventually affect landslide triggering (Galewsky et al., 2006). Landslides appear concentrated in the highest upslope portion of the eastern edges of ENE oriented catchments (i.e., Boca de la Sierra, San Lázaro, Portezuelo). These features might have funneled the wind flow to generate zones where rainfall exceeded estimates considering a flatter topography (Fig. 2), and probably created enhanced wind turbulence not only in the facing slopes but also on the lee side 
(Galewsky et al., 2006) that enhanced vegetation disturbances (e.g., wind shear) and therefore favored slope failures as we interpreted above.

The relatively high proportion of landslides that occurred along the ecotone oak-tropical dry forest also suggests a combined influence of geological and vegetation factors. It is possible that because of the highly dynamic nature of the ecotone area (León-de La Luz and Breceda, 2006), the alternate chemical and biological activity of different vegetation associations have affected physical properties on the substrate. These changes influence, in turn, the susceptibility to slope failure. Chemical weathering in the ecotone region might be different to the one present in more stable inner portions of the oak or tropical dry forests. The original composition of the rocks forming the substrate might also reinforce this differential weathering style; in this case, metamorphic rocks provide a structurally complex system with numerous fractures for roots to deepen and extract more water, but also enabling slopes to develop failure under increased pore pressure in the upper portions of the continuum bedrockregolith-colluvium. A mixed forest structure along the ecotone (León-de la Luz and Breceda, 2006) is also more conducive to heterogeneous concentration of runoff. Combination of upland and lowland tree associations has edge effects on soil moisture and runoff (Joffre and Rambal, 1993; Breshears et al., 1997; Asbjornsen et al., 2004). In addition, the ecotone region can have a wide variety of trees at different heights and stem sizes, creating both weaker forests under strong wind action (Arriaga, 1988) and heterogeneous runoff, because of the differences that the ecotone species might display on the way rainfall is directed from the canopy to the surface. Testing the above hypotheses in this region is out of the scope of the present work, although the confirmation of these ideas represents a key step in order to understand landscape processes in this region and similar areas.

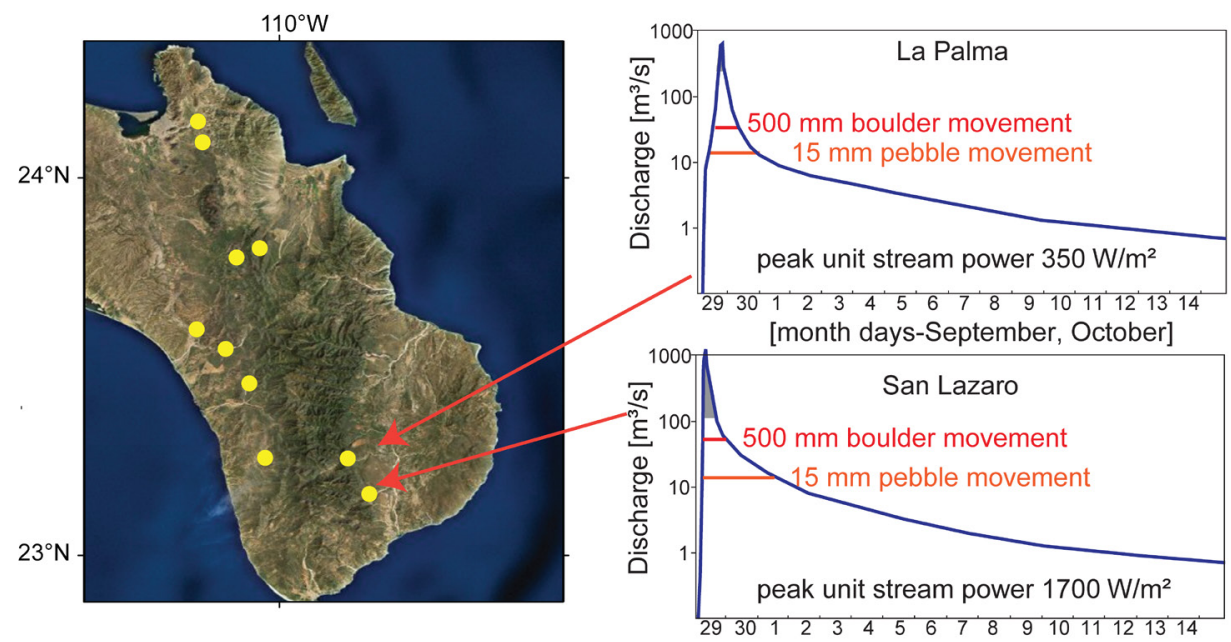

Fig. 14. Hydrographs for La Palma and San Lázaro streams during passage of hurricane Paul (September 29-October 1, 1982). This unique set of flood hydrographs (stations marked as yellow points) was collected in ten small $\left(25-190 \mathrm{~km}^{2}\right)$ catchments by Conagua (available at http://www.imta.gob.mx/index.php?option=com_wrapper\&view=wrapper\&Itemid=145, last accessed 2011/10/10). Peak unit stream power was estimated, based on slope in channel, channel geometry (Bonillas, 1984), and discharge. The shaded area under the peak discharge indicate that during that period the stream was able to carry boulders $>1 \mathrm{~m}$ in diameter. Note that stream power larger than required to move $0.5 \mathrm{~m}$ boulders was sustained during almost $24 \mathrm{~h}$. Discharge measurements for these catchments were discontinued as of 1994 (La Palma) and 1989 (San Lázaro). 


\subsection{Runout of slope failures}

Except for a few landslides occurring directly on the mountain front, most of the slope failures reached streams of second or third order as debris flows. Given the general slope and drainage patterns, these channels joined in short distance streams of higher order with larger discharges capable of carrying the whole landslide load without slowing down the streamflow. Indeed, streams of fourth order (like La Palma or San Lázaro, Fig. 14) can carry more than $1000 \mathrm{~m}^{3} / \mathrm{s}$ during $6 \mathrm{~h}$ or more when a large TC affects the area. Debris deposition was therefore precluded along the mountain mainstems, where stream power reached maximum values, transporting most of the available bedload and suspended load (e.g., Bonillas, 1984), and otherwise eroding. Sediment supplied by landslides entered the flow and was discharged beyond the mountain front.

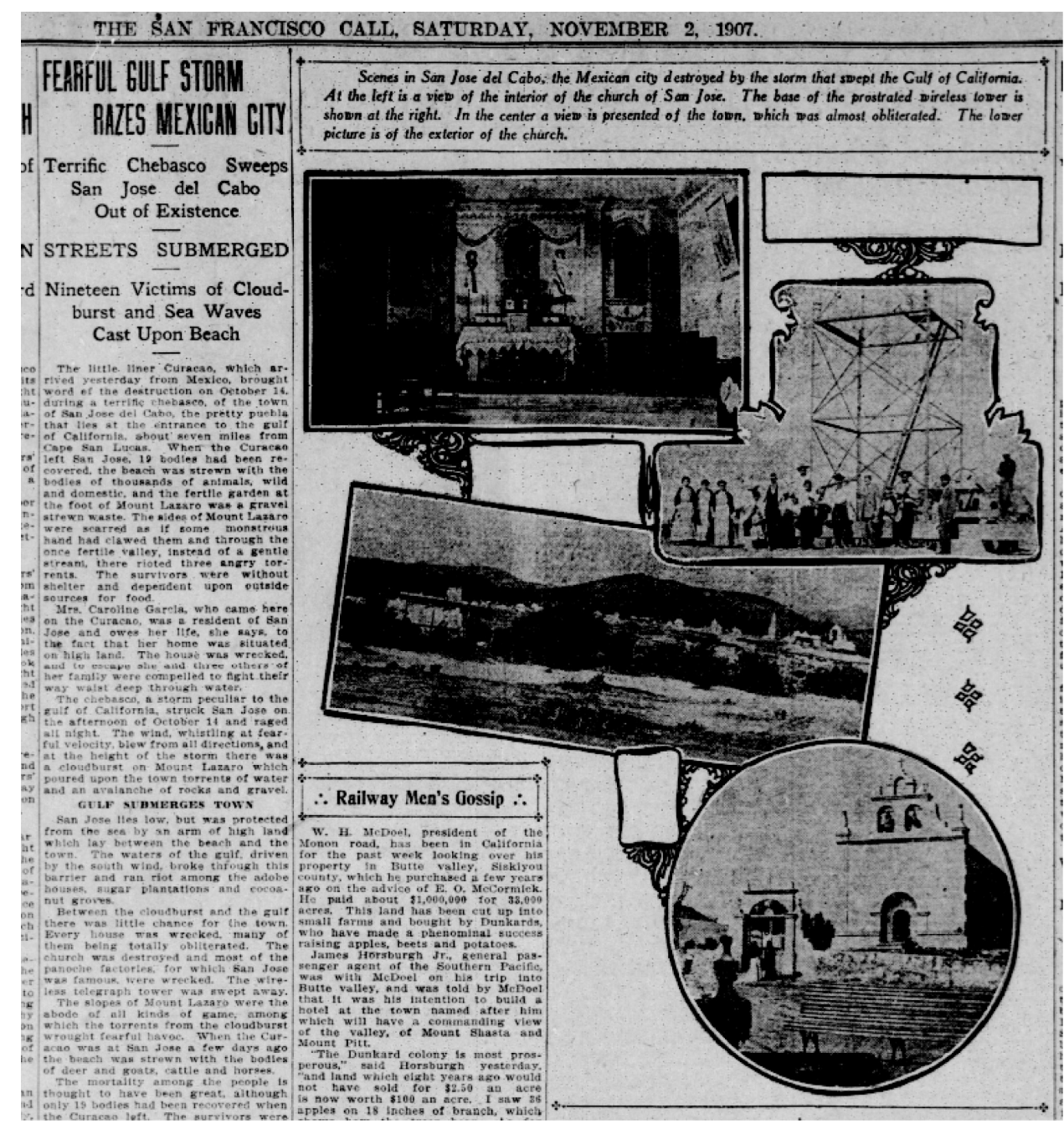

Fig. 15. Clipping from the San Francisco Call, Saturday, November 2, 1907, depicting the damage of a tropical cyclone affecting San José del Cabo and neighboring regions on October 14, 1907. Available at the Online Archive of California: http://www.oac.cdlib.org/ [last accessed 2011/10/10]. 


\subsection{Geomorphic relevance and recurrence of similar landslide events}

\subsubsection{Geomorphic relevance}

The landslides that developed in the SLL during and after the approach of TC Juliette resulted in a large geomorphic effect, removing an important portion of regolith and boulders from the hillslopes, and contributing to sediment transfer to the channels and beyond. Estimated calculations using mean figures for landslide scar size and estimates on scar depth of $\sim 2 \mathrm{~m}$ based on the few field checked events indicate that, for most of the catchments, an average of 2-5 mm surface lowering for the entire catchment can be attributed to this event (Table II). These values, using density adjustments, can be converted to mass transfer rates for these catchments, to compare for example with suspended sediment transport rates in fluvial systems. Similarly, in order to convert this figure to a temporal average that can be used when comparing to tectonic uplift rates or sedimentation rates, an estimation of the recurrence of events as large as TC Juliette is required. In the next paragraphs we obtain an estimation of recurrence based on historical records and also on interpretation of landslide scars from events occurring after this TC.

A. Pre-2001 landslides. An event similar to Juliette should have been noticeable to any observer in the form of hundreds of landslides in the hillslopes. A thorough review of historical records (Antinao and McDonald, 2011) has indicated that at least in the 20th century (e.g., Villanueva, 2001), besides localized mass wasting in areas inside or very close to the main settlements of La Paz and San José del Cabo, few landslides have been recorded as generated by tropical storms in the peninsula. However, one particular record is especially noteworthy and refers to a large TC that occurred in October 1907, where the only explicit mention to landslides in the ca. 300 years of historical records was found (Antinao and McDonald, 2011). A report from the November 2, 1907 edition of the San Francisco Call newspaper (Fig. 15), states: “The sides of Mount Lázaro were scarred as if some monstrous hand had clawed them and through the once fertile valley, instead of a gentle stream, there rioted three angry torrents [...]." From this lines we extract two interpretations: first, failures in the upper portion of the San Lázaro catchment were widespread, with the depiction of a "monstrous hand" indicating several scars on a single hillslope, similar to what happened during the approach of TC Juliette in 2001; second, the type of failures across slopes was similar, the word "scars" depicting what may be the traces of debris flows originating in the upper portion of slopes, reaching the channels.

Reports on the October 1907 event display also other interesting observations: "The [...] liner Curacao [...] brought word of the destruction on October 14, during a terrific chebasco [sic], of the town of San José del Cabo [...] The fertile plain [San José river?] that had yielded several thousand people a comfortable living, had been robbed of its soil by the torrents which had left instead a barren pile of gravel and rocks" (San Francisco Call, November 2, 1907, p. 9). Observations from the effects of Juliette are very similar. However, the damage in 2001 appeared to be more contained and restricted to the riverbed and the lower terraces, and it is likely that the effects of the 1907 event were indeed larger than the ones associated with Juliette. In the early 20th century, after destruction of the old town of San José in 1895 by the effects of another TC (Antinao and McDonald, 2011), the main government buildings had already been relocated to a place closer to their current location; therefore, the larger effects observed in the 1907 flooding would imply a larger flood than in 2001.

The presence of subtle landslide scars, probably triggered by a pre-2001 event in portions of the study area, indicate that at least some events after the 1907 TC have been able to mobilize the hillslopes, but not in the widespread manner that Juliette did. Lack of aerial photography coverage 
$2003 / 05 / 25$

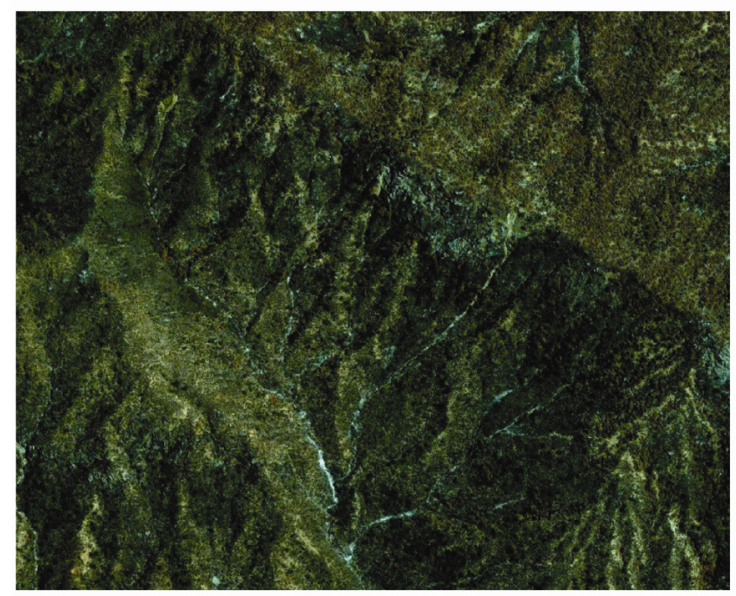

$2003 / 11 / 21$

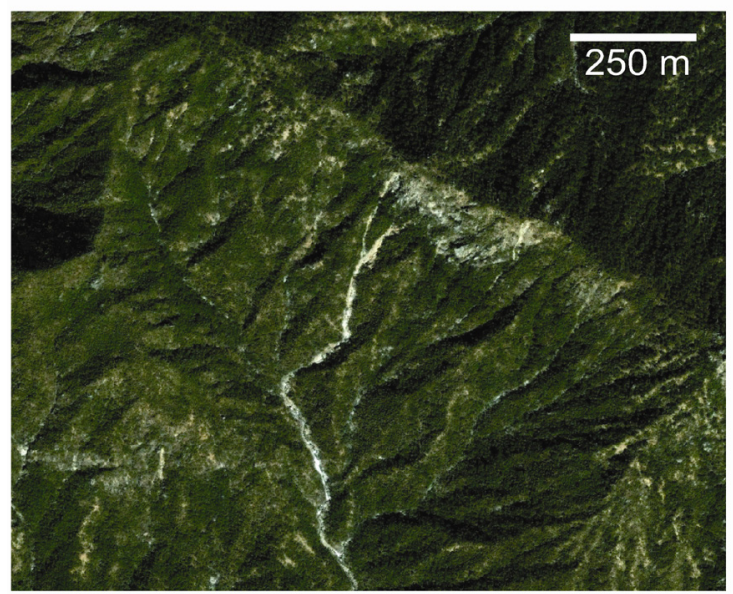

Fig. 16. Pair of GeoEye ${ }^{\circledR}$ images of the upper slopes of the Migriño catchment, western SLL, showing a couple of landslides that appeared probably as a result of hurricane Marty in 2003.

before 1973 hinders the possibility of pinpointing these events, and until other field methods like dendrochronology are used to check timing, it appears that the next older event similar to Juliette, is the 1907 event.

B. Post-TC Juliette landslides. Analyzing post-2001 imagery, we were able to detect landslides generated during the passage of subsequent storms. For example, after the passage of hurricanes Ignacio and Marty in 2003, three landslides are identified in the upper Migriño catchment, at the SLL western slopes (Fig. 16). It is possible that reactivation has occurred in some areas affected in 2001, but in most cases, the slope failures left only bedrock and no further movement is expected in the near future. Based on these observations of events before and after TC Juliette, a conservative estimate for recurrence of events similar to it is the period 1907-2001, or 100 years approximately.

\subsubsection{Sediment transfer rates from landslides to channels}

Individual catchment sediment transfer rates during TC Juliette varied from 2 to $5 \mathrm{~mm}$ of equivalent landscape lowering rate in each individual catchment (Table II). Assuming that the 1907 TC was similar to Juliette, then the time-averaged landscape lowering rate (only considering landslides) from these events is 0.01 to $0.08 \mathrm{~mm}$ per year. This value is in the upper range of estimates for a semiarid, tectonically passive margin (e.g., Bierman and Nichols, 2004), although it is lower than estimates for tectonically active humid areas like Taiwan (Hovius et al., 2000) or Japan (Imaizumi et al., 2008). These rates imply a large amount of sediment transported downstream that must be considered in future management decisions regarding water supply through potential stream damming.

\subsection{Threshold of slope failure}

It has been highlighted that Juliette was exceptional in terms of precipitation (Farfán, 2004), but the relevance of its effects over the entire geomorphic system are less obvious ( $c f$. Martínez- 
Gutiérrez and Mayer, 2004). To clarify the role that Juliette had in comparison to similar, recent meteorological systems, we compiled rainfall intensity and duration from some of the largest storms affecting the region during the last 20 years, and estimated a threshold curve for slope failures (Fig. 17). For example, one of the largest recent storms that brought torrential rains to the SLL (November 1993) was a mesoscale convective system (MCS) that did not cause widespread slope failures based on a survey of Landsat imagery before and after the event. This event brought $>100 \mathrm{~mm} / \mathrm{d}$ to many stations in the southern SLL. The top 10 accumulations were in the range of 120-360 mm/d from November 3 and 4, and the station at Santa Anita (just north of San José del Cabo) recorded $360 \mathrm{~mm}$ on November 3. Similarly, after the passage of Hurricanes Paul (1982) and Isis (1998), both with large effects in the alluvial reaches of all streams originated in the SLL (e.g., Bonillas, 1984), no slope failures were observed in both Landsat imagery and the few available aerial photographs.

The threshold curve derived from the intensity and duration data for these storms, along with Juliette, is strikingly similar not only to curves estimated in wet tropical forest areas affected by TCs (Larsen and Simon, 1993) but also to curves developed for semiarid regions affected by warm-season convective systems (e.g., Webb et al., 2008). Juliette brought more intense rainfall to Baja California than any other storm in record. The lack of an enhanced gauge network in the SLL precludes us from quantifying more precisely this estimated threshold curve or to extend our results to propose a forward predictive model of slope stability. This fact highlights the need of improving the actual hydrometeorological network to better understand slope behavior upon the approach of intense storms like the one analyzed here.

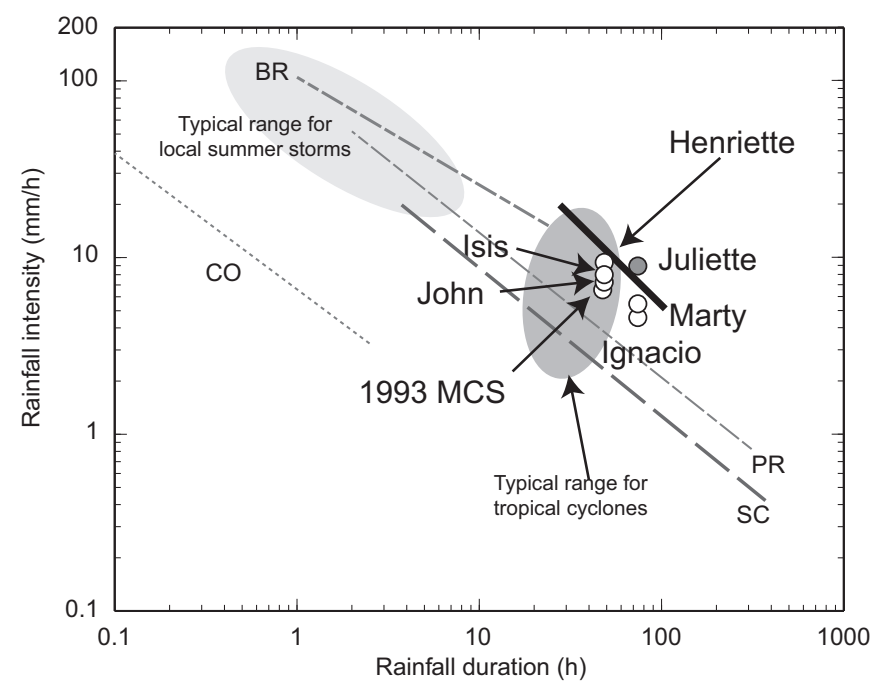

Fig. 17. Graph comparing precipitation intensity and duration thresholds for landslide occurrence in selected regions (dashed gray lines), with conditions for the landfall or approach of several tropical cyclones and local storms that did (gray circles) and did not (white circles) cause landslides in the Sierra la Laguna. Heavy black line is estimated threshold for Sierra la Laguna, fitted visually. The values for storms plotted are based on rainfall data from both daily (15 UTC, 07 local time, at this point measurements restart for the next day) and 10- minute automatic stations. Start and end of rainfall associated with the storm obtained from station records, analysis of GOES imagery and TRMM data. Points are average of the 10 highest rainfall values around SLL. SC: Santa Catalina Mountains, Arizona (Webb et al., 2008); PR: Puerto Rico (Larsen and Simon, 1993); BR: Blue Ridge, Virginia (Wieczorek et al., 2000); CO: southern Rocky Mountains, Colorado (Coe et al., 2008). 


\section{Conclusions}

Sustained high-intensity rainfall associated with the approach of TC Juliette to the southern Baja California peninsula triggered a large amount of landslides in the mountainous terrain of the SLL. Most landslides occurred in a region where total storm precipitation during $c a$. three days was more than $600 \mathrm{~mm}$, and some regions received over $800 \mathrm{~mm}$. The landslides were mostly shallow slips and debris slides of limited areal extent which, given the large amount of streamflow in the drainage network, were converted rapidly into debris flows to be later exported towards the lowlands of the San José del Cabo basin.

The main factors affecting landslide occurrence were total rainfall and intensity, geology and vegetation. The occurrence of landslides was less correlated with antecedent rainfall. Geological features like lithology and fracture spacing probably conditioned strongly not only the direct occurrence of landslides, but also a vegetation influence through the development of different associations linked to them. Meteorological factors like rainfall rates were probably the main triggering factor. Two processes can be distinguished as initiating slope failure. One is rainfall accumulation from exposed bedrock slopes, generating excess overland flow as the main process linked to failures in concave topography. The second process was probably a combination of the wind and excess overland flow in the more convex or planar upper slopes, as uprooted trees dislodged large regolith and bedrock blocks, opening slopes for further runoff concentration partially following the first mentioned process.

A reduced proportion of the landslides accumulated material in the lower slopes, as most of it was carried over by the streams, attesting the high transport capacity that they display during these storms. Landslides are therefore a very efficient mechanism of transferring mass from the hillslopes directly into fourth an fifth order streams that drain outside the SLL range.

The approach of TC Juliette was not only extreme in terms of total and intense rainfall but also in terms of slope failure triggering. When the rainfall data is plotted along with those from other storms that did not cause extensive landsliding, a threshold curve for triggering landslide in this region can be sketched, in a position similar to estimates from other subtropical and tropical areas.

From the analysis of historical information, it is estimated that storms like Juliette approach or make landfall in the southern peninsula on average once every 100 years. Denudation estimates in the form of landscape lowering rates were obtained for several of the catchments where landsliding occurred, and correspond to lower-end estimates of mass transfer for the region, given that smaller events that also transport sediment are not included. Even considering this effect, the rates are in the high end for a tectonically passive margin and highlight the consideration of sediment transfer rates when taking decisions regarding management of water resources in this area through damming streams.

The results emphasize also the need for a more detailed representation of the spatial distribution of rainfall and wind fields for this mountainous region affected by TCs. In particular, an increase in the number of stations representing the higher altitude region of the SLL is needed to more accurately analyze the relation between storm characteristics and landslide occurrence in future events. These analyses represent a key step in order to properly manage this region in terms of water resources and natural hazards. 


\section{Acknowledgments}

We acknowledge US National Science Foundation NSF EAR 1123481 grant and US Army Research Office Contract No. DAAD19-03-1-0159 for supporting this research. J. L. A. was also funded by postdoctoral support funds from the Division of Earth and Ecosystem Sciences (DEES) of the Desert Research Institute. L. M. F. was funded by Conacyt (grant 23448). S. Mayer (CICESE, Unidad La Paz) provided partial logistical support for field activities. E. McDonald (DRI-DEES) participated in field campaigns and discussions on earlier versions of the manuscript during 2010 and 2011.

\section{References}

Alcántara-Ayala I., 2004. Hazard assessment of rainfall induced landsliding in Mexico. Geomorphology 61, 19-40.

Antinao J. L. and J. C. Gosse, 2009. Large rockslides in the southern Central Andes of Chile (32$34.5^{\circ} \mathrm{S}$ ): Tectonic control and significance for Quaternary landscape evolution. Geomorphology 104, 117-133.

Antinao J. L. and E. McDonald, 2011. Three hundred years of hurricanes in Baja California from documentary sources: Implications for sediment flux and landscape evolution in the peninsula. 2011 Annual Conference of the American Association of Geographers. Seattle: AAG, 203.

Arriaga L., 1988. Natural disturbance and tree falls in a pine-oak forest on the Peninsula of Baja California, Mexico. Vegetatio 78: 73-79.

Asbjornsen H., M. Ashton, D. J. Vogt and S. Palacios, 2004. Effects of habitat fragmentation on the buffering capacity of edge environments in a seasonally dry tropical oak forest ecosystem in Oaxaca, Mexico. Agric. Ecosyst. Environ. 103, 481-495.

Ávila L. A., R. J. Pasch, J. L. Beven, J. L. Franklin, M. B. Lawrence, S. R. Stewart and J. Jiing, 2003. Eastern North Pacific hurricane season of 2001. Mon. Weather Rev. 131, 249-262.

Bierman P. R. and K. K. Nichols, 2004. Rock to sediment, slope to sea with 10 Be rates of landscape change. Annu. Rev. Earth Planet. Sci. 32, 215-255.

Bonillas E., 1984. Análisis hidrológico de la zona sur del estado de Baja California Sur. Bachelor's thesis, Universidad de Sonora. Hermosillo, Sonora, Mexico, 126 pp.

Breshears D. D., P. M. Rich, F. J. Barnes and K. Campbell, 1997. Overstory-imposed heterogeneity in solar radiation and soil moisture in a semiarid woodland. Ecol. Appl. 7, 1201-1215.

Bucknam R. C., J. A. Coe, M. M. Chavarria, J. W. Godt, A. C. Tarr, L. A. Bradley, S. Rafferty, D. Hancock, R. L. Dart and M. L. Johnson, 2001. Landslides triggered by hurricane Mitch in Guatemala. Inventory and discussion. U.S. Geological Survey Open File Report 01-443. Denver: USGS, 40 pp.

Camacho-Valdez V., J. M. Murillo-Jiménez, E. H. Nava-Sánchez and C. Turrent-Thompson, 2008. Dune and beach morphodynamics at Cabo Falso, Baja California Sur, Mexico: Response to natural, hurricane Juliette (2001) and anthropogenic influence. J. Coastal Res. 24, 553-560.

Coe J. A., D. A. Kinner and J. W. Godt, 2008. Initiation conditions for debris flows generated by runoff at Chalk Cliffs, central Colorado. Geomorphology 96, 270-297.

Consejo de Recursos Minerales, 2002. Carta geológico-minera San José del Cabo (F12-2-3-5-6). México: Sener (1:250 000 scale map).

Consejo de Recursos Minerales, 2008. Carta geológico-minera San José del Cabo (F12-B44). México: Sener (1:50 000 scale map). 
Crone A. J., R. L. Baum, D. J. Lidke, D. N. D. Sather, L. Bradley and A. C. Tarr, 2001. Landslides induced by hurricane Mitch in El Salvador-An inventory and descriptions of selected features. U. S. Geological Survey Open File Report 01-444. Denver: USGS, 24 pp.

Cruden D. M. and D. J. Varnes, 1996. Landslide types and processes. Special report 247: Landslides: Investigation and Mitigation (A. K. Turner and R. L. Schuster, eds.). Washington, DC: Transportation and Road Research Board, National Academy of Science, 36-75.

Farfán L. M., 2004. Regional observations during the landfall of tropical cyclone Juliette (2001) in Baja California, Mexico. Mon. Weather Rev. 132, 1575-1589.

Farfán L. M., R. Romero-Centeno and G.B. Raga, 2012, Observations and forecasts from the landfall of tropical cyclones John, Lane and Paul (2006) over northwestern Mexico. Weather Forecast. 27, 1373-1393.

Galewsky J., C. P. Stark, S. Dadson, C. Wu, A. H. Sobel and M. Horng, 2006. Tropical cyclone triggering of sediment discharge in Taiwan. J. Geophys. Res. 111, F03014.

Griffiths P. G., R. H. Webb and T. H. Melis, 2004. Frequency and initiation of debris flows in Grand Canyon, Arizona. J. Geophys. Res. 109, doi:10.1029/2003JF000077.

Gupta A., 1988. Large floods as geomorphic events in the humid tropics. Flood Geomorphology (V. R. Baker, R. C. Kochel and P. C. Patton., Eds.) New York: John Wiley \& Sons, 301-315.

Hovius N., C. P. Stark, C. Hao-Tsu and L. Jiun-Chuan, 2000. Supply and removal of sediment in a landslide-dominated mountain belt: Central range, Taiwan. J. Geol. 108, 73-89.

Imaizumi F., R. C. Sidle and R. Kamei, 2008. Effects of forest harvesting on occurrence of landslides and debris flows in steep terrain of central Japan. Earth Surf. Proc. Land. 33, 827-840.

INEGI, 2005. Carta de uso de suelo y vegetación. Series III (2002) y IIIg (2002) (continuo nacional). Mexico: Instituto Nacional de Estadística, Geografía e Informática (1:250 000 scale map).

INEGI, 2007. Conjunto de datos vectorial edafológico. Serie II (continuo nacional). Mexico: Instituto Nacional de Estadística, Geografía e Informática (1:250,000 scale map).

Joffre R. and S. Rambal, 1993. How tree cover influences the water balance of Mediterranean rangelands. Ecology 74, 570-582.

Johnson A. M. and J. R. Rodine, 1984. Debris flow. In: Slope instability (D. Brundsen and D. B. Prior, eds.). Hoboken, N.J.: John Wiley \& Sons, 257-361,

Koch S., M. des Jardins and P. Kocin, 1983. An interactive Barnes objective map analysis scheme for use with satellite and convectional data. J. Appl. Meteorol. 22, 1487-1503.

Kostaschuk R., J. Terry and R. Raj, 2001. Tropical cyclones and floods in Fiji. Hydrolog. Sci. J. 46, 435-450.

Larsen M. C. and A. J. Torres-Sanchez, 1992. Landslides triggered by hurricane Hugo in eastern Puerto Rico, September 1989. Caribb. J. Sci. 28, 113-125.

Larsen M. and A. Simon, 1993. A rainfall intensity-duration threshold for landslides in a humidtropical environment, Puerto Rico. Geogr. Ann. A 75, 13-23.

Larsen M., 2008. Rainfall-triggered landslides, anthropogenic hazards and mitigation strategies. Advances in Geosciences 14, 147-153.

Latorre C. and L. Penilla, 1988. Influencia de los ciclones en la precipitación de Baja California Sur. Atmósfera 1, 99-112.

León-de la Luz J. L. and A. Breceda, 2006. Using endemic plant species to establish critical habitats in the Sierra de la Laguna biosphere reserve, Baja California Sur, Mexico. Biodivers. Conserv. 15, 1043-1055. 
León-de la Luz J. L. and R. Domínguez-Cadena, 2010. Using endemic plant species to establish critical habitats in the Sierra de la Laguna biosphere reserve, Baja California Sur, Mexico. Can. J. For. Res. 40, 2059-2068.

Lin C., C. Shieh, B. Yuan, Y. Shieh, S. Liu and S. Lee, 2004. Impact of Chi-Chi earthquake on the occurrence of landslides and debris flows: example from the Chenyulan River watershed, Nantou, Taiwan. Eng. Geol. 71, 49-61.

Malamud B., D. Turcotte, F. Guzzetti and P. Reichenbach, 2004. Landslides, earthquakes and erosion. Earth Planet. Sc. Lett. 229, 45-59.

Martínez-Gutiérrez G. and L. Mayer, 2004. Huracanes en Baja California, México, y sus implicaciones en la sedimentación en el Golfo de California. GEOS 24, 57-64.

Martínez-Gutiérrez G., J. J. Díaz-Gutiérrez and O. Cosío-González, 2010. Análisis morfométrico en la cuenca hidrológica San José del Cabo, B.C.S., México: una aproximación en la identificación de potenciales áreas de captura. Rev. Mex. Cienc. Geol. 27, 581-592.

Matías-Ramírez L. G., 1998. Algunos efectos de la precipitación del huracán Paulina en Acapulco, Guerrero. Investigaciones Geográficas 37, 7-20.

Millard T., 2003. Schmidt Creek sediment sources and the Johnstone Strait killer whale rubbing beach. Nanaimo, B.C. Ministry of Forests, Vancouver Forest Region, 12 pp.

Milliman, J. D. and S. Kao, 2005. Hyperpycnal discharge of fluvial sediment to the ocean: Impact of super-typhoon Herb (1996) on Taiwanese rivers. J. Geol. 113, 503-516.

Padilla-Lozoya R., 2006. El huracán del 59. Historia del desastre y reconstrucción de Minatitlán, Colima. Colima, Mexico: Universidad de Colima, 180 pp.

Page M. J., L. M. Reid and I. H. Lynn, 1999. Sediment production from cyclone Bola landslides, Waipoa catchment. J. Hydrol. 38, 289-308.

Restrepo C. and N. Álvarez, 2006. Landslides and their contribution to land-cover change in the mountains of Mexico and Central America. Biotropica 38, 446-457.

Serra S., 1971. Hurricanes and tropical storms of the west coast of Mexico. Mon. Weather Rev. 99, 302-308.

Turton S. M., 2008. Landscape-scale impacts of cyclone Larry on the forests of northeast Australia, including comparisons with previous cyclones impacting the region between 1858 and 2006 . Austral. Ecology 33, 409-416.

Villanueva E., 2001. Presencia de huracanes en Baja California Sur. El caso del ciclón Liza. Tesis de maestría, Universidad Autónoma de Baja California Sur. La Paz, B.C.S., Mexico, 279 pp.

Webb R. H., C. S. Magirl, P. G. Griffiths and D. E. Boyer, 2008. Debris flows and floods in the southeastern Arizona from extreme precipitation in July 2006: Magnitude, frequency and sediment delivery. U.S. Geological Survey Open File Report 1274. Denver: USGS, 95 pp.

Wieczorek G. F., B. A. Morgan and R. H. Campbell, 2000. Debris-flow hazards in the Blue Ridge of central Virginia. Environ. Eng. Geosci. VI, 3-23. 